Mikrochim. Acta 111, 119-125 (1993)

$\underset{\text { Acta }}{\text { Mikrochimica }}$

by Springer-Verlag 1993

Printed in Austria

\title{
2-(2-Thiazolylazo)-p-Cresol (TAC) as a Reagent for the Spectrophotometric Determination of Titanium (IV)
}

\author{
Sérgio L. C. Ferreira ${ }^{1, *}$, A. C. Spínola Costa ${ }^{1}$, and Henrique A. S. Andrade ${ }^{2}$ \\ ${ }^{1}$ Instituto de Quimica, Universidade Federal da Bahia, Salvador, Bahia, 40210, Brasil \\ ${ }^{2}$ Dept. de Química, Pontificia Universidade Católica, Rio de Janeiro, RJ, 22453, Brasil
}

\begin{abstract}
The reaction between titanium(IV) and 2-(2-thiazolylazo)-p-cresol(TAC) in aqueous methanol media at apparent $\mathrm{pH} 4.0-5.6$ results in a intensely coloured complex that is stable for at least $2 \mathrm{~h}$. The combining ratio is $1: 1$ cation: TAC. Beer's law is obeyed up to $5.0 \mu \mathrm{g} / \mathrm{ml}$ titanium(IV) at $580 \mathrm{~nm}$. The apparent molar absorptivity at $580 \mathrm{~nm}$ is $9.82 .10^{3} 1 . \mathrm{mole}^{-1} . \mathrm{cm}^{-1}$ and the detection limit obtained was $5 \mathrm{ng} / \mathrm{ml}$ titanium(IV). A spectrophotometric method for the simultaneous determination of titanium and iron with TAC is proposed.
\end{abstract}

Key words: 2-(2-thiazolylazo)-p-cresol, titanium determination, simultaneous determination.

Hydrogen peroxide [1] is commonly used for the spectrophotometric determination of titanium. The method is simple and fairly selective, but not very sensitive (the apparent molar absorptivity is $\left.7001 . \mathrm{mole}^{-1} \mathrm{~cm}^{-1}\right)$. 2-(2-Thiazolylazo)-p-cresol (TAC) is an alternative, it reacts with titanium(IV), forming a $1: 1$ complex with an apparent molar absorptivity of $9.82 .10^{3} 1 . \mathrm{mole}^{-1} . \mathrm{cm}^{-1}$ at $580 \mathrm{~nm}$, in the presence of hydroxylammonium chloride. Iron(II) also reacts with TAC $[2,3]$ to give a complex with composition $\mathrm{Fe}(\mathrm{II})-(\mathrm{TAC})_{2}$ and absorption peaks at 740,580 and $520 \mathrm{~nm}$. It is thus possible to determine titanium(IV) and iron(II) spectrophotometrically with TAC in a single sample.

TAC has also been used for the spectrophotometric determination of copper(II) [4], nickel [5], bismuth [6], and zirconium [7].

* To whom correspondence should be addressed 


\section{Experimental}

\section{Reagents}

TAC Solution: $0.1 \mathrm{~g}$ dissolved in $100 \mathrm{~mL}$ of methanol.

Standard titanium solution [8]: prepared by heating $0.20 \mathrm{~g}$ of titanium(IV) oxide with $8 \mathrm{ml}$ of concentrated sulphuric acid and $3.2 \mathrm{~g}$ of ammonium sulphate until dissolved, cooling, and diluting to 1 litre with water.

Standard iron(II) solution: prepared by dissolving $0.176 \mathrm{~g}$ of iron(II) ammonium sulphate in $0.5 \%$ (v/v) sulphuric acid.

Buffer solution: prepared by mixing $2.0 \mathrm{M}$ sodium acetate and $2.0 \mathrm{M}$ acetic acid in appropriate ratio to give $\mathrm{pH} 5$.

Stock solutions of others elements: prepared by dissolving suitable salts in water, $1 \%(\mathrm{v} / \mathrm{v})$ nitric acid or $1 \%(\mathrm{v} / \mathrm{v})$ hydrochloric acid.

Hydroxylammonium chloride solution: prepared by dissolving $10 \mathrm{~g}$ of the salt in $100 \mathrm{ml}$ of water.

Procedure for Titanium in the Absence of Iron

Into a $25-\mathrm{ml}$ standard flask, transfer a portion of solution containing up to $125 \mu \mathrm{g}$ of titanium(IV). Add $2.5 \mathrm{ml}$ of hydroxylammonium chloride solution, $8 \mathrm{ml}$ of methanol, $2 \mathrm{ml}$ of TAC solution and $5 \mathrm{ml}$ of acetate buffer. Dilute to the mark with water, mix and after 5 min measure the absorbance at $580 \mathrm{~nm}$ in a 1-cm cell, using an appropriate blank. Prepare a calibration graph covering the range up to $125 \mu \mathrm{g}$ of titanium per $25 \mathrm{ml}$.

\section{Procedure for Iron in the Absence of Titanium}

To a 25 -ml standard flask containing up to $100 \mu \mathrm{g}$ of iron, add $2.5 \mathrm{ml}$ of hydroxylammonium chloride solution, $8 \mathrm{ml}$ of methanol, $2 \mathrm{ml}$ of TAC solution and $5 \mathrm{ml}$ of acetate buffer. Dilute to the mark with water, mix, and measure the absorbance at 580 or $740 \mathrm{~nm}$ using a blank. Prepare a calibration graph covering the range up to $100 \mu \mathrm{g}$ of iron per $25 \mathrm{ml}$.

\section{Procedure for Determination of Both Titanium and Iron in Geological Matrices}

Sample Decomposition. Weigh $0.2-0.3 \mathrm{~g}$ of sample (dried at $110^{\circ} \mathrm{C}$ ), transfer it into a Teflon beaker, add a few $\mathrm{ml}$ of water, $1 \mathrm{ml}$ of concentrated sulphuric acid and $10 \mathrm{ml}$ of concentrated hydrofluoric acid, and heat on a hot-plate until white fumes appear. Cool, add 5-10 $\mathrm{ml}$ of concentrated hydrochloric acid and transfer the contents of the beaker to a 25 -ml glass beaker. Heat until all the residue has dissolved, cool to room temperature, and transfer the solution into a convenient size of standard flask; make up to volume with demineralized water.

Analysis. Pipette a suitable volume of the sample solution into a $250-\mathrm{ml}$ beaker, and heat it on a hot-plate almost to dryness. Cool, add $2.5 \mathrm{ml}$ of hydroxylammonium chloride solution and transfer the solution to a $25-\mathrm{ml}$ standard flask. Add $8 \mathrm{ml}$ of methanol, $2 \mathrm{ml}$ of TAC solution and $5 \mathrm{ml}$ of acetate buffer. Measure the absorbances at 740 and $580 \mathrm{~nm}$, against a reagent blank run through the whole procedure.

Calculation Method for Simultaneous Determination of Titanium and Iron

1. Method (a)

$$
\begin{aligned}
& \mathrm{A}_{740}=\mathrm{e}_{740}^{\mathrm{Fe}} \cdot \mathrm{b} \cdot \mathrm{C}^{\mathrm{Fe}} \\
& \mathrm{A}_{580}=\mathrm{e}_{580}^{\mathrm{Fe}} \cdot \mathrm{b} \cdot \mathrm{C}^{\mathrm{Fe}}+\mathrm{e}_{580}^{\mathrm{Ti}} \cdot \mathrm{b} \cdot \mathrm{C}^{\mathrm{Ti}}
\end{aligned}
$$

This method does not consider the weak absorption of the titanium-TAC complex at $740 \mathrm{~nm}$. 
2. Method (b)

$$
\begin{aligned}
& A_{-740}=e_{740}^{\mathrm{Fe}} \cdot b \cdot C^{\mathrm{Fe}}+\mathrm{e}_{740}^{\mathrm{Ti}} \cdot b \cdot C^{\mathrm{Ti}} \\
& A_{-580}=\mathrm{e}_{580}^{\mathrm{Fe}} \cdot b \cdot C^{\mathrm{Fe}}+\mathrm{e}_{580}^{\mathrm{Ti}} \cdot b \cdot C^{\mathrm{Ti}}
\end{aligned}
$$

This method consider the weak absorption of the titanium-TAC complex at $740 \mathrm{~nm}$.

\section{Results and Discussion}

Solubility of $T A C$

TAC is only slightly soluble in water but readily soluble in aqueous media containing $20 \%$ or more methanol, ethanol, 2-propanol, acetone, dioxan or ethylene glycol. Methanol, ethanol and ethylene glycol are preferred as the absorbance of the titanium complex is higher in these media and remains stable for at least one hour.

\section{Reaction Conditions}

Maximal and constant absorbance is obtained for $50 \mu \mathrm{g}$ of titanium(IV) with $0.70 \mathrm{ml}$ of $0.1 \%$ TAC solution per $25 \mathrm{ml}$; so, $2.00 \mathrm{ml}$ of TAC solution was selected as optimal.

The complex formation is greatly influenced by the $\mathrm{pH}$, Table 1 shows that the best $\mathrm{pH}$ range is $4.0-5.6$. The absorbance is somewhat dependent on the buffer concentration (shown in Table 2), it is necessary to use the same buffer concentration for all samples, standards and blanks.

The order of addition was studied and the results demonstrated that the complex was affected with it. The results showed (Table 3 ) that the reductant must be always added before the buffer.

A preliminary experiment showed that the Ti(IV)-TAC system is not stable in the absence of hydroxylammonium chloride (Table 4).

Table 5 shows that with titanium(IV) concentration of $2.0 \mu \mathrm{g} / \mathrm{ml}$, the absorbance of the system is not affected by the presence of from 1 to $6 \mathrm{ml}$ of a $10 \%$ solution of

Table 1. Effect of $\mathrm{pH}$ on complex formation. (Ti(IV): $2.00 \mu \mathrm{g} / \mathrm{ml}$ )

\begin{tabular}{ll}
\hline $\mathrm{pH}$ & Absorbance \\
\hline 3.00 & 0.047 \\
3.46 & 0.105 \\
3.78 & 0.364 \\
4.00 & 0.382 \\
4.56 & 0.402 \\
5.13 & 0.396 \\
5.64 & 0.383 \\
5.81 & 0.372 \\
6.23 & 0.366 \\
\hline
\end{tabular}

Table 2. Effect of the concentration buffer on the TI(IV)-TAC system. (Ti(IV): $2.00 \mu \mathrm{g} / \mathrm{ml}$; pH 5.0)

\begin{tabular}{ll}
\hline $\begin{array}{l}\text { Buffer acetate } \\
\text { concentration }(M)\end{array}$ & $\begin{array}{l}\text { Absorbance at } \\
580 \mathrm{~nm}\end{array}$ \\
\hline 0.10 & 0.416 \\
0.20 & 0.405 \\
0.30 & 0.391 \\
0.40 & 0.377 \\
0.50 & 0.365 \\
\hline
\end{tabular}


Table 3. Effect of order of addition or on the formation of the Ti(IV)-TAC complex. (Ti(IV): $2.00 \mu \mathrm{g} / \mathrm{ml}$ )

\begin{tabular}{ll}
\hline Order of addition & Absorbance \\
\hline Titanium + Chloride + Alcohol + TAC + Buffer + Water & $0.405^{\mathrm{b}}$ \\
Titanium + Chloride + Buffer + Alcohol + TAC + Water & 0.403 \\
Titanium + Chloride + TAC + Alcohol + Buffer + Water & 0.405 \\
Titanium + Chloride + TAC + Buffer + Alcohol + Water & 0.406 \\
Titanium + TAC + Chloride + Buffer + Alcohol + Water & 0.404 \\
Titanium + Alcohol + Chloride + TAC + Buffer + Water & 0.405 \\
Titanium + Buffer + Chloride + TAC + Alcohol + Water & 0.390 \\
Titanium + TAC + Alcohol + Buffer + Chloride + Water & 0.339 \\
Titanium + TAC + Buffer + Chloride + Alcohol + Water & 0.396 \\
Titanium + Buffer + TAC + Alcohol + Chloride + Water & 0.366 \\
\hline
\end{tabular}

a Chloride $=$ Hydroxylammonium chloride.

b Average of three determinations.

hydroxylammonium chloride in a $25 \mathrm{ml}$ total of solution. A potentiometric titration revealed that the titanium(IV) is not reduced by the hydroxyammonium chloride, which suggest that this salt takes part in the complex formation. The Ti(IV)-TAC complex is not formed in the presence of other reducing agents such as hydrazine sulphate or ascorbic acid. A comparison of the spectra of titanium(IV)-TAC with and without hydroxylammonium chloride present shows that there is no difference between the positions of the absorbance maxima.

Accordingly, we conclude that as Ti(IV): TAC ratio was found to be $1: 1$, a ternary Ti(IV): TAC: $\left(\mathrm{NH}_{2} \mathrm{OH}\right)_{\mathrm{X}}$ complex is formed, but the value of $\mathrm{x}$ could not

Table 4. Effect of the hydroxylammonium chloride $[\mathrm{X}]$ on the stability of the Ti(IV)-TAC system. (Ti(IV): $2.53 \mu \mathrm{g} / \mathrm{m}$ )

\begin{tabular}{llll}
\hline \multicolumn{5}{c}{ Absorbance } & \\
\cline { 2 - 4 } Time (min) & $([\mathrm{X}], 0 \%)$ & $([\mathrm{X}], 0.40 \%)$ & $([\mathrm{X}], 2.40 \%)$ \\
\hline 0 & 0.236 & 0.490 & 0.502 \\
5 & 0.168 & 0.496 & 0.507 \\
10 & 0.163 & 0.494 & 0.503 \\
15 & 0.160 & 0.494 & 0.503 \\
20 & 0.157 & 0.493 & 0.503 \\
25 & 0.156 & 0.493 & 0.504 \\
30 & 0.155 & 0.494 & 0.501 \\
35 & 0.153 & 0.492 & 0.501 \\
40 & 0.153 & 0.492 & 0.501 \\
45 & 0.153 & 0.491 & 0.501 \\
50 & 0.151 & 0.491 & 0.501 \\
55 & 0.151 & 0.491 & 0.503 \\
60 & 0.149 & 0.490 & 0.501 \\
\hline
\end{tabular}

Table 5. Effect of the hydroxylammonium chloride concentration $[\mathrm{X}]$ on the Ti(IV)-TAC system. (Ti(IV): $2.00 \mu \mathrm{g} / \mathrm{ml}$ )

\begin{tabular}{ll}
{$[\mathrm{X}](\%)$} & Absorbance $(580 \mathrm{~nm})$ \\
\hline 0.50 & 0.380 \\
1.00 & 0.404 \\
2.00 & 0.403 \\
3.00 & 0.402 \\
4.00 & 0.404 \\
5.00 & 0.405 \\
6.00 & 0.405 \\
\hline
\end{tabular}


be determined by the conventional methods, owing to the low stability of the system without this reactant. A $1: 2: 2: 4 \mathrm{Ti}(\mathrm{IV}): \mathrm{NH}_{2} \mathrm{OH}$ : Pyrocatechol Violet : Cetyltrimethylammonium complex has been reported [9] which lends credence to this supposition.

\section{Calibration Curve}

The calibration curves were made under the conditions described above. The results are shown in Table 6.

\section{Interferences}

The selectivity of the reaction was investigated by determining $12.5 \mu \mathrm{g}$ of titanium in the presence of various amounts of other ions. The tolerance level for an ion was taken as the amount which caused a change of $\pm 2 \%$ in the absorbance of the chelate. It was found that copper(II), nickel(II), iron(II), cobalt(II) and indium(III) interfere even at $1-\mu \mathrm{g}$ level. Magnesium, calcium, barium, strotium, aluminium and thalluim-

Table 6. Characteristics of the Ti(IV)-TAC and Fe(II)-(TAC) $)_{2}$ systems

\begin{tabular}{llll}
\hline System & $\lambda(\mathrm{nm})$ & $\varepsilon(\mathrm{pH} 5.0) 1 . \mathrm{mole}^{-1} \mathrm{~cm}^{-1}$ & Obedience to Beer's Law \\
\hline Ti(IV)-TAC & 580 & $9.82 .10^{3}$ & $0-125 \mu \mathrm{g}$ \\
& 740 & $3.40 .10^{2}$ & - \\
Fe(II)-(TAC) ${ }_{2}$ & 520 & $1.51 .10^{4}$ & $0-100 \mu \mathrm{g}$ \\
& 580 & $1.08 .10^{4}$ & $0-125 \mu \mathrm{g}$ \\
& 740 & $1.18 .10^{4}$ & $0-125 \mu \mathrm{g}$ \\
\hline
\end{tabular}

$\hat{\lambda}=$ Absorption peak.

$\varepsilon=$ Apparent absorption.

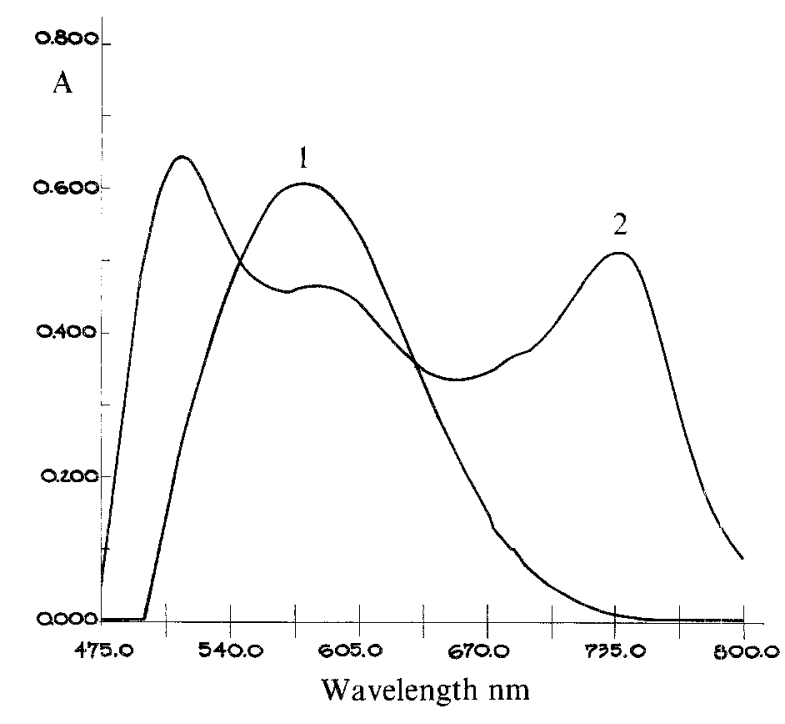

Fig. 1. Absorption spectra. 1 Ti(IV)(TAC); $2 \mathrm{Fe}(\mathrm{II})-(\mathrm{TAC})_{2}$ 
(III) did not interfere even at $200: 1$ (w/w) ratio to titanium, but there was interference from vanadium(V) $(260 \mu \mathrm{g})$, manganese(II) $(650 \mu \mathrm{g})$, lanthanum $(850 \mu \mathrm{g})$, cadmium $(260 \mu \mathrm{g})$, lead $(80 \mu \mathrm{g})$, yttrium $(40 \mu \mathrm{g})$, gallium $(30 \mu \mathrm{g})$, zirconium $(40 \mu \mathrm{g})$, platinum(IV) $(60 \mu \mathrm{g})$ and gold(III) $(80 \mu \mathrm{g})$.

Table 7. Simultaneous determination of iron and titanium

\begin{tabular}{lllllllr}
\hline $\begin{array}{l}\text { Standard or } \\
\text { sample }\end{array}$ & $\begin{array}{l}\text { No. of } \\
\text { dets. }\end{array}$ & $\begin{array}{l}\mathrm{TiO}_{2}(\%) \\
\text { present }\end{array}$ & $\begin{array}{l}\mathrm{TiO}_{2}(\%) \\
\text { found }\end{array}$ & $\begin{array}{l}\mathrm{TiO}_{2}(\%) \\
\text { found }\end{array}$ & $\begin{array}{l}\mathrm{Fe}_{2} \mathrm{O}_{3}(\%) \\
\text { present }\end{array}$ & $\begin{array}{l}\mathrm{Fe}_{2} \mathrm{O}_{3}(\%) \\
\text { found }\end{array}$ & $\begin{array}{l}\mathrm{Fe}_{2} \mathrm{O}_{3}(\%) \\
\text { found }\end{array}$ \\
\hline Bauxite NBS & 10 & 2.78 & $2.73 \pm 0.04$ & $2.74 \pm 0.05$ & 5.82 & $5.79 \pm 0.09$ & $5.79 \pm 0.08$ \\
Clay1-IPT & 4 & 0.24 & $0.26 \pm 0.06$ & $0.26 \pm 0.05$ & 1.94 & $2.01 \pm 0.06$ & $2.00 \pm 0.05$ \\
Clay2-IPT & 6 & 0.54 & $0.59 \pm 0.06$ & $0.60 \pm 0.06$ & 1.46 & $1.49 \pm 0.11$ & $1.47 \pm 0.10$ \\
Clay3-IPT & 4 & 1.04 & $1.11 \pm 0.02$ & $1.08 \pm 0.02$ & 1.28 & $1.32 \pm 0.08$ & $1.30 \pm 0.09$ \\
Basalt & 4 & 1.11 & $1.22 \pm 0.17$ & $1.23 \pm 0.15$ & 9.72 & $9.46 \pm 0.06$ & $9.45 \pm 0.05$ \\
Granite & 4 & 0.26 & $0.25 \pm 0.02$ & $0.25 \pm 0.03$ & 1.62 & $1.84 \pm 0.10$ & $1.85 \pm 0.09$ \\
Clay4-IPT & 4 & 1.40 & $1.45 \pm 0.02$ & $1.43 \pm 0.02$ & 1.56 & $1.57 \pm 0.06$ & $1.53 \pm 0.06$ \\
Clay-BA & 3 & 0.81 & $0.75 \pm 0.08$ & $0.74 \pm 0.07$ & 7.68 & $7.57 \pm 0.06$ & $7.57 \pm 0.06$ \\
Bentonite-PB & 3 & 1.18 & $1.26 \pm 0.04$ & $1.27 \pm 0.03$ & 9.21 & $9.48 \pm 0.08$ & $9.48 \pm 0.08$ \\
Bauxite 1-MG & 3 & 1.32 & $1.45 \pm 0.04$ & $1.44 \pm 0.05$ & 10.26 & $10.25 \pm 0.08$ & $10.26 \pm 0.09$ \\
Bauxite 2-MG & 3 & 1.19 & $1.16 \pm 0.04$ & $1.16 \pm 0.05$ & 9.44 & $9.28 \pm 0.14$ & $9.29 \pm 0.13$ \\
Cement-BA & 3 & 0.22 & $0.21 \pm 0.02$ & $0.22 \pm 0.03$ & 3.33 & $3.18 \pm 0.12$ & $3.16 \pm 0.10$ \\
\hline
\end{tabular}

a Method (a), 95\% confidence limit.

b Method (b), 95\% confidence limit.

c The compositions are shown in Table 8 .

Table 8. Composition of standards and samples analysed

\begin{tabular}{lcccccccc}
\hline $\begin{array}{l}\text { Standard and } \\
\text { sample }\end{array}$ & $\begin{array}{l}\mathrm{Al}_{2} \mathrm{O}_{3} \\
(\%)\end{array}$ & $\begin{array}{l}\mathrm{Fe}_{2} \mathrm{O}_{3} \\
(\%)\end{array}$ & $\begin{array}{l}\mathrm{TiO}_{2} \\
(\%)\end{array}$ & $\begin{array}{l}\mathrm{SiO}_{2} \\
(\%)\end{array}$ & $\begin{array}{l}\mathrm{CaO} \\
(\%)\end{array}$ & $\begin{array}{l}\mathrm{MgO} \\
(\%)\end{array}$ & $\begin{array}{l}\mathrm{Na}_{2} \mathrm{O} \\
(\%)\end{array}$ & $\begin{array}{l}\mathrm{K}_{2} \mathrm{O} \\
(\%)\end{array}$ \\
\hline $\begin{array}{l}\text { Bauxite NBS- } \\
\quad \text { USA }^{\mathrm{a}}\end{array}$ & 55.00 & 5.82 & 2.78 & 6.01 & 0.29 & 0.02 & 0.02 & 0.01 \\
Clay 1-IPT-SPa $^{\mathrm{a}}$ & 38.40 & 1.94 & 0.24 & 45.10 & 0.07 & 0.14 & 0.01 & 0.85 \\
Clay 2-IPT-SP $^{\mathrm{a}}$ & 35.90 & 1.46 & 0.54 & 48.00 & 0.06 & 0.24 & 0.01 & 0.91 \\
Clay 3-IPT-SP $^{\mathrm{a}}$ & 29.10 & 1.28 & 1.04 & 55.80 & 0.09 & 0.20 & 0.01 & 0.29 \\
Clay 4-IPT-SP $^{\mathrm{a}}$ & 45.00 & 1.56 & 1.40 & 30.70 & 0.07 & 0.13 & 0.06 & 1.26 \\
Basalt & 15.48 & 9.72 & 1.11 & 56.14 & 7.54 & 4.36 & 2.75 & 2.07 \\
Granite- $^{\mathrm{a}}$ & 15.06 & 1.62 & 0.26 & 71.80 & 1.21 & 0.50 & 3.79 & 4.78 \\
Clay-BA $^{\mathrm{b}}$ & 16.36 & 7.68 & 0.81 & - & 3.26 & 3.15 & 0.56 & 2.56 \\
Bentonite-PB $^{\mathrm{b}}$ & 20.72 & 9.21 & 1.18 & - & 0.48 & 2.47 & 0.51 & 1.18 \\
Bauxite 1-MG $^{\mathrm{b}}$ & 53.25 & 10.26 & 1.32 & - & 0.06 & 0.05 & 0.20 & 0.29 \\
Bauxite 2-MG $^{\mathrm{b}}$ & 61.47 & 9.44 & 1.19 & - & 0.04 & 0.05 & 0.06 & 0.03 \\
Cement-BA $^{\mathrm{b}}$ & 3.67 & 3.33 & 0.22 & - & 53.10 & 1.81 & 0.23 & 0.48 \\
\hline
\end{tabular}

a Standards.

b Samples (analysed by ICP in CEPED).

IPT Instituto de Pesquisa Tecnológica São Paulo; SP Brasil. CEPED Centro de Pesquisa e Desenvolvimento da Bahia Camaçari; Ba Brasil. 
Sulphosalicylic acid, cyanide, bromide, chloride, glycine, borate, sulphate, iodide, thiosulphate and thiourea did not interfere at $1000: 1 \mathrm{w} / \mathrm{w})$ ratio to titanium, but there was interference from EDTA $(2.5 \mu \mathrm{g})$, NTA $(2.5 \mu \mathrm{g}), 1,10$-phenanthroline $(125 \mu \mathrm{g})$, sulphide $(125 \mu \mathrm{g})$, tartrate $(400 \mu \mathrm{g})$, citrate $(400 \mu \mathrm{g})$, phosphate $(400 \mu \mathrm{g})$ and fluoride $(400 \mu \mathrm{g})$ in the amounts shown in the brackets.

\section{Determination of Titanium and Iron}

Although iron(II) interferes very strongly in the titanium determination, the reaction of $\mathrm{Fe}$ (II) with TAC yields a complex [composition $\mathrm{Fe}(\mathrm{II})-(\mathrm{TAC})_{2}$ ] with absorption peaks at 740, 580 and $520 \mathrm{~nm}$. Whereas the Ti-TAC complex has only one absorption peak, at $580 \mathrm{~nm}$, and practically zero absorbance at $740 \mathrm{~nm}$ (Fig. 1).

Simultaneous determination of titanium and iron is therefore possible, by measuring the absorbances at 580 and $740 \mathrm{~nm}$, and calculation based on the additive property of the absorbances. Ideally, a correction should be included for the slight absorbance of the Ti complex at $740 \mathrm{~nm}$, but as shown in Table 7, this is not necessary for routine analyses.

\section{Application}

The method was applied to simultaneous determination of iron and titanium in various standards and samples (Table 8). The results (Table 7) indicate that the accuracy and precision for the proposed method are satisfactory. To obtain higher signals, $2-\mathrm{cm}$ cuvettes were used. The method of calculation based on the measure of the absorbance at $740 \mathrm{~nm}$ for the iron and at $580 \mathrm{~nm}$ for the titanium and iron cannot be applied if the titanium amount is much higher than that of iron, in the sample.

Analysis of synthetic samples showed that the method can be used for samples with iron/titanium ratios in the range from $20: 1$ to $1: 3$.

Acknowledgements. The authors acknowledge the financial support of the CNPq and CAPES (Brazil).

\section{References}

[1] Z. Marczenko, Spectrophotometric Determination of Elements, Horwood, Chichester, 1976.

[2] K. Ueda, S. Sakamoto, Y. Yamamoto, Nippon Kagaku Kaishi 1981, 7, 1111.

[3] L. P. Silva, MSc. Thesis, PUC Rio de Janeiro, 1989.

[4] L. Sommer, M. Langová, V. Kubán, Collection Czech. Chem. Commun. 1976, 41, 1317.

[5] S. L. C. Ferreira, Talanta 1988, 35, 485.

[6] C. Tsurumi, K. Furuya, H. Kamata, Nippon Kagaku Kaishi 1977, 10, 1469.

[7] S. I. Gusev, N. F. Gavrilova, G. A. Kurepa, L. V. Poplevina, Zh. Anal. Khim. 1974, 29, 1955.

[8] I. M. Kolthoff, P. J. Elving, Treatise on Analytical Chemistry, Part II, Vol. 5, Interscience, New York, 1961, p. 16.

[9] D. Zang, X. Zeng, Fenxi Hanxue 1986, 14, 498. 